\title{
Democratizar a jurisdição constitucional? O caso das audiências públicas no Supremo Tribunal Federal
}

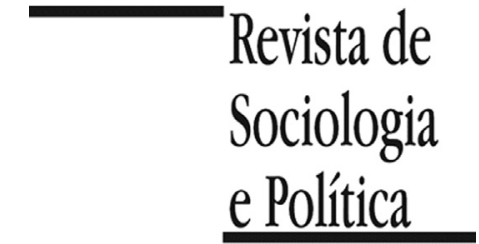

DOI 10.1590/1678-987317256206

\author{
Marjorie Corrêa Marona e Marta Mendes da Rocha
}

\begin{abstract}
Resumo
Este artigo se insere no conjunto de análises acerca do fenômeno da judicializacão da política no Brasil, considerando a atuação do Supremo Tribunal Federal (STF) no exercício do controle de constitucionalidade das leis e atos normativos. O objeto de análise são as audiências públicas realizadas pelo STF no período de 2007 a 2014, com o objetivo de verificar em que medida elas vêm se convertendo em um mecanismo capaz de ampliar o caráter deliberativo da corte e fomentar o diálogo e a interface entre atores estatais e societais, ampliando, assim, a base informacional e a legitimidade de suas decisões. Foram analisadas todas as audiências públicas, excluídas aquelas para as quais os dados não estavam disponíveis. O estudo envolveu análise em perspectiva comparada, longitudinal e transversal, e análise documental a partir de um quadro analítico construído em torno das dimensões de interesse. Foi realizada uma caracterização pormenorizada das audiências públicas - regras, temas, atores, formatos e dinâmica de interação. Além disso, foram identificados os elementos comuns aos eventos, suas singularidades, as alterações ao longo do tempo, os avanços e os limites no que se refere ao uso que a corte vem realizando das audiências públicas. O artigo inova ao explorar as possibilidades teóricas associadas à análise das relações entre constitucionalismo e democracia, partindo da tradição dicotômica que se estabeleceu desde as origens das democracias constitucionais até perspectivas dialógicas mais recentes. Considerando as peculiaridades que cercam a atuação do STF nos últimos anos, destaca-se a urgência desse debate para o caso brasileiro e propõe-se a análise do funcionamento de um mecanismo institucional de introdução relativamente recente. Até onde temos conhecimento não há nenhum trabalho que tenha se proposto a uma análise tão pormenorizada das audiências públicas do STF.
\end{abstract}

PALAVRAS-CHAVE: audiências públicas; Supremo Tribunal Federal; legitimidade; participação; diálogo interinstitucional.

Recebido em 8 de Março de 2016. Aceito em 7 de Junho de 2016.

\section{Introdução ${ }^{1}$}

\footnotetext{
1 Agradecemos aos valiosos comentários e críticas dos pareceristas da Revista de Sociologia e Política que contribuíram sobremaneira para o aperfeiçoamento do texto.

2 Vianna et al., 1999;

Carvalho Neto 2007; 2008; 2009; 2010; 2013; Couto \& Arantes 2006; Engelmann 2015; Engelmann \& Penna 2014; Engelmann \& Cunha Filho 2013; Nobre 2008; Nobre \& Rodriguez 2011; Rodriguez 2010; Maciel \& Koerner 2002; Oliveira 2005; Da Ros 2012; 2013; Taylor \& Da Ros 2008; Tomio \& Robl Filho 2015; Tomio \& Carvalho Neto 2013.

${ }^{3}$ A partir desse ponto referimo-nos ao Supremo
}

\begin{abstract}
A s análises acerca do poder Judiciário no Brasil e, especialmente, daquilo que se convencionou chamar de judicialização da política, são hoje bastante variadas e em número suficiente para que se possa dizer que se conformou uma agenda de pesquisa minimamente consistente em torno da questão do protagonismo social e político que os tribunais alcançaram no interior das democracias ocidentais contemporâneas ${ }^{2}$.

Não por acaso, essa agenda opera, fundamentalmente, a partir da atuação do Supremo Tribunal Federal ${ }^{3}$ (Sarmento 2015), particularmente no exercício do controle de constitucionalidade das leis e atos normativos, e coloca a questão da legitimidade democrática de sua atuação. A judicialização da política foi, desde a originária incursão de Tate e Vallinder (1995) sobre a expansão do poder das cortes constitucionais nas democracias liberais contemporâneas, associada ao processo histórico de constitucionalização dos regimes democráticos, ou seja, vinculada ao surgimento de Estados no âmbito dos quais era possível que se exercesse um controle jurisdicional sobre a vida política nacional. A possibilidade de as cortes constitucionais intervirem em decisões políticas emanadas dos tradicionais órgãos representativos (Legislativo e Executivo) suscitou a questão da legitimidade, assente na pressuposição de uma relação de tensão entre
\end{abstract}


Tribunal Federal como STF ou simplesmente Supremo, indistintamente.

${ }^{4}$ Doravante "APs". constitucionalismo e democracia (Elster \& Slagstadt 1988) que organiza o debate em termos dicotômicos (Mendes 2011; 2013). Além disso, fez com que as tradicionais fronteiras entre Direito e política e entre liberdades individuais e soberania popular fossem mitigadas em prol da compreensão do papel político que os tribunais exercem, particularmente, no âmbito da jurisdição constitucional.

Essa é uma questão particularmente sensível para a democracia brasileira, considerando as peculiaridades do desenho constitucional legado do processo de redemocratização, que ampliou o conjunto de temas de natureza constitucional passíveis de serem judicializados e adjudicou competências superlativas ao Supremo Tribunal Federal (Vieira 2008). À corte brasileira foi facultado não apenas o exercício de autoridade - inerente a qualquer intérprete constitucional - mas também de poder, tradicionalmente reservado a órgãos representativos, sujeitos ao controle democrático. A regulamentação pormenorizada de um amplo campo das relações sociais, econômicas e políticas, em uma espécie de compromisso maximizador, reorganizou o sistema político estatal (Vieira et al. 2013), conformando um novo padrão de relação entre a corte e as tradicionais esferas representativas (Presidência da República e Congresso Nacional), mas também entre ambas e a sociedade.

Na última década, o STF tem se manifestado sobre questões de máxima relevância política, social e econômica, sendo notável, nesse tocante, a ampliação da representação e da participação de atores sociais no âmbito do controle judicial de constitucionalidade, com destaque para a ampliação do rol de legitimados para a propositura das ações constitucionais no Brasil (art. 103 da Constituição da República Federativa do Brasil de 1988), mas, especialmente, para a criação da figura do amicus curiae e para a previsão e realização das audiências públicas ${ }^{4}$ no STF (Avritzer \& Marona 2014).

Sob o pano de fundo dos debates acerca da legitimidade democrática da atuação do Supremo, pretendemos, neste artigo, analisar as audiências públicas realizadas pelo Supremo Tribunal Federal entre os anos de 2007 e 2014, buscando desvendar sua vocação no interior do sistema político brasileiro, particularmente no campo das complexas relações interinstitucionais e socioestatais. A introdução das audiências públicas no controle concentrado de constitucionalidade suscitou um interessante debate sobre os potenciais do mecanismo para ampliar a legitimidade da atuação da corte e introduzir uma dimensão participativo-deliberativa no processo (Vestena 2012; Naves 2012). Tais reflexões tangenciam, ainda, outra questão, referente à capacidade das APs de ativar a legitimidade reflexiva do STF (Rosanvallon 2011) ao multiplicar os enfoques parciais e plurais na construção do bem comum.

O artigo apresenta os resultados parciais de um projeto de investigação mais amplo $^{5}$ que tem como objetivo analisar e avaliar os impactos das audiências públicas realizadas pelo Supremo Tribunal Federal, considerando seu potencial de representatividade política (Almeida 2015) no interior de um amplo sistema deliberativo que articula Estado e sociedade (Parkinson \& Mansbridge 2012). Aqui, concentramo-nos em uma das dimensões analíticas destacadas no plano geral da referida pesquisa, qual seja, aquela que remete, ao mesmo tempo, à inclusão e à participação de diferentes atores e perspectivas no processo, e ao diálogo e interface entre Estado e sociedade.

$\mathrm{O}$ artigo está organizado da seguinte maneira. Na primeira seção exploramos as possibilidades teóricas associadas à análise das relações entre constitucionalismo e democracia, partindo da tradição dicotômica que se estabeleceu desde as origens das democracias constitucionais até perspectivas dialógicas mais recentes. Ainda nessa seção salientamos a urgência deste debate no 
conformação de uma interface socioestatal.

${ }^{6} \mathrm{O}$ acesso à íntegra da audiência, na forma de notas taquigráficas, foi possível em oito casos; nos outros sete, o acesso esteve restrito à relação de habilitados para participar e ao cronograma (STF s.d.). cenário brasileiro, considerando as peculiaridades que cercam a atuação do STF nos últimos anos.

Na segunda seção abordamos o instrumento da audiência pública, de modo geral, situando-o como um entre os vários mecanismos e formas de participação que se multiplicaram no Brasil nas últimas décadas. Além disso, sumarizamos algumas das preocupações e conclusões dos estudos sobre audiências públicas, especialmente, no âmbito do STF. Na terceira seção apresentamos um panorama das audiências públicas realizadas entre 2007 e 2014, suas regras, formato de organização e condução dos trabalhos, número e perfil dos participantes. Nosso estudo compreende o período de 2007 a 2014, no qual o STF realizou 16 audiências públicas. A análise, contudo, se restringiu a 15 casos por não termos tido acesso às informações referentes a uma das audiências públicas.

O estudo envolveu análise documental de diversas peças processuais, particularmente dos despachos que continham decisões de convocação, relação de habilitados e o cronograma de quinze APs realizadas no período, além da íntegra das notas taquigráficas das oito APs para as quais elas estavam disponíveis ${ }^{6}$. Realizou-se um esforço de comparação entre os eventos ao longo do tempo, de modo a identificar os aspectos mais centrais que marcaram o uso do instrumento, mapear semelhanças e diferenças, regularidades e descontinuidades. No intuito de compreender o significado da presença desta inovação institucional no âmbito da jurisdição constitucional, buscamos verificar os sentidos atribuídos pelos ministros às APs, a partir da análise das falas dos relatores dos processos nos quais elas ocorreram e de outros atores-chave.

Finalmente, na quarta e última seção apresentamos as considerações finais e alguns apontamentos para avançar nesta agenda de pesquisa. Nossos achados nos permitem, além de uma caracterização das audiências públicas (regras, organização, formato e condução), algumas conclusões sobre o grau de inclusividade que elas promovem, na medida em que fomentam o diálogo entre atores estatais e societais e promovem um aporte informacional ao processo decisório (Almeida 2015). Além disso, destacamos aquilo que percebemos como limites ao funcionamento das APs e ao aproveitamento de suas potencialidades.

\section{As cortes constitucionais: diálogo, deliberação e representação}

Os contornos hegemônicos do constitucionalismo contemporâneo foram forjados ainda no século XIX, nos Estados Unidos da América, quando a Suprema corte, no célebre caso Marbury vs. Madison, estabeleceu a premissa da supremacia da Constituição. Já o processo de redemocratização da Europa após a II Guerra Mundial foi responsável por pinceladas inovadoras, fundadas na positivação de princípios de justiça nos textos constitucionais e na aposta nas potencialidades da jurisdição e das cortes constitucionais para a garantia de sua efetivação.

Pode-se dizer que o sucesso dessas experiências induziu à generalização de um novo modelo ocidental-liberal de democracia, a partir da segunda metade do século XX, caracterizado pelo estabelecimento da jurisdição constitucional e pela transformação das cortes constitucionais em uma arena fundamental no âmbito do sistema político (Tate \& Vallinder 1995). Contudo, o protagonismo assumido gradativamente pelas cortes constitucionais foi cercado de divergências, especialmente acerca da compatibilidade de sua atuação com o princípio democrático - a soberania popular. Diante disso, a tradição teórica que se estabeleceu no campo de disputa entre constitucionalismo e democracia seguiu um modelo dicotômico: os dilemas sobre quem, em uma democracia constitucional, deve ter a "última palavra" (Mendes 2013) sobre decisões políticas 
fundamentais, podem ser resgatados na base da oposição entre categorias (supostamente) contrapostas - Direito e política, razão e interesse etc.

De fato, a tradição liberal, na sua contemporânea vertente igualitária, assume como pressuposto a capacidade de os indivíduos construírem um consenso sobre princípios de justiça - os quais são procedimentais e devem ser incorporados pela ordem constitucional. Esta, por sua vez, funda a ordem pública, situando-se acima das variadas concepções de bem características de uma sociedade plural (Rawls 2002). Nesses termos, as cortes constitucionais são ora tomadas como lócus da razão pública (Dworkin 2012), ora são destacadas como um interlocutor institucional (Mendes 2011), ora são caracterizadas por sua própria capacidade de deliberar (Ferejohn \& Pasquino 2002).

A dicotomia entre constitucionalismo e democracia se renova, contemporaneamente, na disputa protagonizada por Ronald Dworkin $(1995$; 1999) e Jeremy Waldron $(1994 ; 1999)$. Para Dworkin a democracia diz respeito ao bem/interesse geral, à policy, às decisões que se legitimam pelos critérios do quem decide (órgãos representativos) e de como se decide (regra da maioria). As constituições, por sua vez, são o berço dos princípios, dizem respeito àquelas decisões que se legitimam pelo seu conteúdo (a resposta certa, o princípio de justiça). Waldron argumenta, em contraponto, que diante do desacordo moral reinante em sociedades marcadas pelo pluralismo valorativo, não há ajuste possível sobre conteúdo (princípios de justiça, direitos fundamentais) que seja anterior ou independa do próprio processo democrático. Diante disso, avança o argumento da necessidade de um concerto procedimental para conformação do conteúdo, que prime pela maximização do direito de participação. Nesses termos, faz a justiça depender da democracia.

Interessa, particularmente nesse ponto, a perspectiva $d$ workeana, pelo relevo que empresta à capacidade argumentativa das cortes, com o que inaugura toda uma nova linha de reflexões no campo - que se expande pelos Estados Unidos, Alemanha, Espanha, África do Sul e Colômbia - e se sustenta na ideia de que o Direito retira sua legitimidade de uma cultura de justificação (Sachs 2009; Woolman \& Bishop 2008) a qual é parte fundante de democracias genuínas (Mendes 2013).

Para Dworkin $(1995 ; 1999)$ a democracia envolve requisitos substantivos que são atendidos pela resposta certa em termos de direitos fundamentais. A introdução desse elemento epistêmico possibilita ao autor afirmar que, inspirado em um ideal de igual consideração e respeito, o constitucionalismo propicia a filiação moral de cada pessoa à comunidade política, sem a qual os procedimentos majoritários não têm valor. Ronald Dworkin é provavelmente o maior entusiasta da ideia de que as cortes produzem razão e se constituem como um fórum de princípios em uma democracia ${ }^{7}$.

A consideração de uma dimensão argumentativa e racional de democracia, que não se limita aos procedimentos agregativos e ao princípio majoritário, faz depender também da atuação das cortes constitucionais o padrão de legitimidade dos regimes democráticos liberais, na medida em que elas operam a partir do elemento epistêmico que qualifica o decision making (Landemore 2013). Ademais, a percepção das cortes como public reasoners promove a vinculação de sua atuação à dimensão deliberativa da democracia para além do que havia previsto o próprio Habermas (1995), possibilitando que as cortes sejam pensadas, elas mesmas, como atores argumentativos. Particularmente, as teorias do diálogo interinstitucional (Bickel 1986) evidenciam a dimensão temporal da política, propondo um diálogo cooperativo e permanente entre as instituições que, por meio de suas particulares expertises e contextos decisórios, devem ser parceiras na busca pela melhor interpretação constitucional, exigindo-se circularidade e complementaridade infinitas entre os poderes da república ${ }^{8}$ - o que re- 
Bruce Ackerman lança mão dessa ideia ao interpretar a separação de poderes nos Estados Unidos da América, quando desenvolve o argumento do dualismo constitucional, que comporta a alternância entre momentos de política normal e constitucional (Ackerman 1993). define o debate acerca da legitimidade democrática das cortes, pensada em termos reflexivos (Rosanvallon 2011).

Nesses termos, abre-se a possibilidade para reposicionamento da atuação das cortes no interior de uma cadeia decisória deliberativa, pressupondo a sua capacidade em proporcionar uma razão prudencial de acautelar o sistema político contra assaltos majoritários, e retardar o processo decisório institucionalizado, esperando que o tempo possa contribuir para uma decisão com maior densidade deliberativa (Ferejohn \& Pasquino 2002; Mendes 2011). Ademais, o reconhecimento de que há vida constitucional para além das cortes constitucionais possibilita que a decisão judicial possa ser encarada apenas como uma etapa de um estágio do decision making, de modo que o processo de interpretação constitucional seja circular e ininterrupto, pois o significado da Constituição não pode ser presumido - ele precisa ser politicamente construído. As cortes constitucionais reassumiriam a possibilidade de produzir vetos qualificados pela linguagem do Direito, enriquecendo a qualidade argumentativa da democracia por proporcionar uma interlocução interinstitucional que contribui para a construção de seu elemento epistêmico (Landemore 2013).

As críticas à narrativa da fundação contratual moderna sob a qual se funda o constitucionalismo liberal (Sousa Santos 2010) se desdobram em questionamentos dirigidos à ideia de uma razão pública, encarnada na institucionalidade, e à tradicional função estabilizadora da Constituição, identificada como um brutal mecanismo de manutenção de exclusões estruturais (Fraser 2009). A possibilidade permanente de revisão democrática, ampla e plural da Constituição é considerada, nesta perspectiva crítica, uma oportunidade de reconstrução dos frames da comunidade política (Fraser 2009), o que transforma a jurisdição constitucional em um campo de lutas, em uma atividade política e social permanentes, evidenciando a natureza contingente da justiça (Mendonça \& Marona 2015).

Nesse sentido, a justiça e a Constituição se tornariam necessariamente dependentes da democracia, ao mesmo tempo em que a alimentariam, de modo que o movimento constitucional se somaria à democracia, internalizando parte da sua instabilidade, mas também da sua capacidade criativa, emancipatória (Mendonça \& Marona 2015). Reconhece-se, assim, que as cortes constitucionais são afetadas pelo ambiente político que as circunda (Friedman 2009) ao mesmo tempo em que sobre ele atuam (Baird 2007). Constrói-se, nesses termos, uma expectativa em torno da capacidade de as cortes constitucionais estimularem o diálogo político e social, em um processo de aproximação e distanciamento alternado da opinião popular, ora representando seus anseios mais claros, outrora liderando na persecução de caminhos inovadores, em um movimento que forja a sua representatividade política em termos de uma reflexividade que não pode se limitar a uma intervenção dos experts, senão que exige a multiplicação de fóruns híbridos que reúnam cientistas e cidadãos para debater questões essenciais (Rosanvallon 2011).

O argumento epistêmico (Landemore 2013; Barroso 2015) não é de todo afastado - e há registros acerca do processo deliberativo interno às cortes - mas o que se sublinha é que as cortes não estão no vácuo, que precisam de cooperação, contribuindo, por sua vez, para a intensidade e a racionalidade do diálogo, na medida em que promovem a coleta de argumentos, sintetiza-os, pauta a discussão, faz escolhas, direciona, catalisa, provoca e modera, causando perturbação no status quo (Mendes 2013), especialmente em casos relevantes para a política nacional e para a opinião pública. Desse modo, o processo de legitimação da corte vai além das vias formais e envolve deliberação com o público, o que sugere que os ministros atuam de forma proativa, moldando, por 
meio de suas decisões, na relação com o público, a própria agenda da corte (Baird 2007).

E, nesse sentido, considerando que existem muitas formas - em disputa ou complementares ao voto - de se produzir legitimidade democrática pela realização de uma generalidade social que extrapola os padrões de formação e identificação, típicos da democracia representativa eleitoral (Rosanvallon 2011), é que surge a questão sobre o impacto das audiências públicas na construção da legitimidade democrática do STF. A questão da legitimidade democrática das cortes ganha, portanto, novos contornos. As cortes participam de uma dialética construtiva com o sistema representativo que obriga a maioria a integrar raciocínios e outros argumentos, enquanto se encontra simultaneamente sujeita aos embates da minoria e à disciplina da justiça constitucional (Almeida 2015).

Particularmente, interessa entender o modo pelo qual as audiências públicas, ao fomentarem o diálogo e a interface com atores societais, podem contribuir para a integração do Supremo Tribunal Federal em uma dinâmica deliberativa que ative sua legitimidade reflexiva ao multiplicar os enfoques parciais e plurais na construção do bem comum. Para tanto, considera-se que "a exigência de reflexividade não pode se limitar a uma crescente intervenção dos experts, sendo necessário multiplicar fóruns híbridos que reúnam cientistas e cidadãos para debater questões essenciais" (Almeida 2011, p.163).

No Brasil, a ambição constitucional contida no texto original de 1988, a regulamentar, pormenorizadamente, um amplo campo de relações sociais, políticas e econômicas, potencializou as estratégias de constitucionalização do Direito ordinário, reposicionando os tribunais, as demais instituições do sistema de justiça e em especial o STF, no âmbito do processo de construção das decisões políticas fundamentais da república. Foi instituído, ademais, um amplo e complexo sistema de controle judicial de constitucionalidade das leis e atos normativos, no interior do qual o STF ganhou, ao longo dos anos, cada vez mais centralidade. De fato, no Brasil, o controle repressivo de constitucionalidade é feito por juízes e tribunais e se dá por meio de dois sistemas - difuso e concentrado - exercidos, respectivamente, por todos os integrantes do poder Judiciário e pelo Supremo Tribunal Federal, consolidando um sistema híbrido de controle judicial de constitucionalidade bastante singular.

Inspirado no modelo europeu, o STF faz vezes de corte constitucional ao atuar no controle (concentrado) de constitucionalidade das leis, o que poderia situá-lo num ponto independente dos três poderes. Contudo, suas competências revisionais em matéria constitucional, que remetem à tradição norte-americana, o incluem dentre os órgãos do poder Judiciário. E, nesse último caso, o STF só se destaca como guardião da Constituição pela força vinculante de suas decisões, geralmente em sede de Recurso Extraordinário, que podem levar a questão constitucional até o STF que, então, "atuará como órgão de cúpula do Judiciário e suas decisões valerão apenas para as partes concretamente envolvidas" (Arantes 2013). Entretanto, mesmo quando exerce o controle difuso de constitucionalidade, teoricamente mais descentralizado, a competência recursal do STF torna ainda mais nítida sua função de guardar e uniformizar a interpretação do texto constitucional, mormente depois das modificações introduzidas pela Emenda Constitucional $n^{\circ} 45 / 20036$, ponto culminante do processo de reforma do Judiciário brasileiro.

O STF possui, nesse quadrante, competências superlativas (Vieira 2008; Vieira et al., 2013). A singularidade do arranjo institucional brasileiro induz à crescente autoridade do STF em relação às demais instâncias do Judiciário e, especialmente, à expansão de sua autoridade em relação aos outros poderes, de modo bastante peculiar (Vieira 2008; 2013). De fato, na última década, o STF manifestou-se acerca de inúmeras questões de grande repercussão política e so- 
cial, tais como demarcação de terras indígenas, nepotismo, fidelidade partidária, lei de biossegurança e inelegibilidade, uso de algemas, aborto no caso de anencefalia, Sistema Único de Saúde, políticas afirmativas raciais, dentre outras - boa parte das quais veiculadas por meio de ações constitucionais.

Em um contexto em que o Judiciário assume funções que são, também, políticas - especialmente no âmbito da jurisdição constitucional - sua legitimidade democrática pode ser repensada em termos reflexivos (Rosanvallon 2011), atrelada à capacidade institucional da corte constitucional para ser uma arena que integra um sistema de discussão pública, em uma democracia na qual as questões controversas são debatidas e as decisões são publicamente justificadas. As audiências públicas, nesse quadrante, podem oferecer uma oportunidade interessante para a problematização de questões teóricas que se encontram na interseção de diferentes campos no interior da teoria política e democrática; daí a importância de definir o seu caráter e a sua função.

O desenvolvimento dos potenciais associados às APs depende, nesse sentido, da forma como o desenho institucional das audiências e a forma como elas vêm efetivamente sendo mobilizadas pelos ministros, promove a inclusão de atores, agendas, problemas e interesses; a diversificação e pluralização no contexto de tomada de decisões; a promoção de um debate qualificado entre os atores da sociedade civil e entre estes e os ministros; a interação, de fato, entre os participantes; o aporte de informação para a decisão; o fomento a um processo deliberativo mais amplo que se desenrola em diferentes contextos e em presença de variados atores.

\section{Audiências públicas: potencialidades e limites}

As audiências públicas, de modo genérico, têm sido frequentemente analisadas na perspectiva teórica da participação social: elas constituem um recurso bastante utilizado pelo Legislativo e vem ganhando espaço, também, no Executivo, no Brasil (Pires \& Vaz 2012). Não há consenso em relação a uma definição de audiência pública na literatura acadêmica especializada, mas da forma como vêm sendo praticadas nas casas legislativas brasileiras, as APs consistem em reuniões abertas promovidas pelas comissões parlamentares, das quais podem participar legisladores, cidadãos, representantes de entidades da sociedade civil, técnicos e especialistas com o objetivo de promover o debate em torno de temas ou questões de interesse público na área da respectiva comissão.

Nas últimas décadas, vimos no Brasil uma notável multiplicação de mecanismos de participação cidadã que buscam promover a interação e a colaboração entre cidadãos, grupos sociais e autoridades públicas (Avritzer 2009). Estas inovações estão presentes antes, durante e depois do processo de tomada de decisões, no âmbito da formulação, mas também da implementação e monitoramento de políticas públicas. Trata-se de uma experiência que se disseminou no Brasil contemporâneo, marcado pela institucionalização e pelo desenvolvimento de instâncias como os conselhos gestores de políticas públicas, as conferências temáticas, as audiências e consultas públicas, ouvidorias e outros (Pires \& Vaz 2012).

Estas experiências fazem parte de um repertório institucional de participação que tem avançado no Brasil e que promove a interação de atores sociais junto a atores estatais e entre representantes de diferentes instituições, associações ou outros coletivos populares, forjando novas formas de representação política (Lavalle et al. 2011). Os potenciais comumente associados às experiências participativas institucionalizadas são o aumento da transparência nos processos de tomada de decisão e de gestão, a maior responsabilização das autoridades e dos órgãos públicos, a criação de oportunidades para vocalização 
${ }^{9}$ Nos Estados Unidos as audiências públicas, desde os anos 1980, já eram reconhecidas como um dos métodos mais tradicionais de participação cidadã, presentes em todos os níveis de governo e cada vez mais frequentes em número e diversificadas em seus usos (Checkoway 1981, p.566).

${ }^{10}$ Na própria Assembleia Nacional Constituinte, as audiências públicas desempenharam um papel de relevo "tanto pela diversidade de participantes e setores representados como pelas centenas de propostas e inúmeras polêmicas surgidas" (Backes, Azevedo \& Araújo 2009). de preferências com a incorporação de novos atores e interesses, e a consequente diversificação da agenda pública, além da ampliação da legitimidade das decisões fundamentadas em ampla inclusão dos interessados. Estes mecanismos, dentre os quais se destacam os conselhos e as conferências de políticas públicas, diferenciam-se quanto ao tipo de inclusão e de interação que promovem, ao público-alvo a que se dirigem, em sua periodicidade, entre outros aspectos (Avritzer 2009; Lavalle et al. 2011; Almeida \& Cunha 2012).

Há algum tempo bastante disseminadas no âmbito do Executivo e do Legislativo, as experiências de participação social têm se tornado relevantes, também, no âmbito do poder Judiciário, como evidencia estudo do IPEA que mostra que, em 2002, "órgãos como Justiça Federal, Justiça do Trabalho, Justiça Eleitoral, Ministério Público, STJ, e STF não contavam com qualquer programa no qual fosse incentivada a adoção de interface socioestatal", mas essa situação se altera "em 2010, pois todos estes órgãos declararam ter implementado tais mecanismos em seus respectivos programas" (Pires \& Vaz 2012, p.11).

Não resta dúvidas, portanto, de que a audiência pública é um instrumento de participação popular ${ }^{9}$. Está prevista na Constituição de $1988^{10}$, que em seu art. 58 dispõe que às comissões da Câmara dos Deputados e do Senado Federal cabem, em razão da matéria de sua competência, realizar audiências públicas com entidades da sociedade civil. Existe, ademais, regulação na legislação infraconstitucional e, na Câmara dos Deputados, as regras e procedimentos para realização de audiências públicas estão definidos nos art. 255 a 258 do regimento interno. Já no Senado Federal, a disposição sobre APs engloba os arts. 93 a 95 do respectivo regimento interno. Em ambos os casos o expediente é considerado uma forma das comissões parlamentares instruírem matéria legislativa em trâmite, bem como tratarem de assuntos de interesse público relevante.

No poder Judiciário, a previsão de realização de audiências públicas no âmbito da jurisdição constitucional remete à publicação da Lei nº 9868/99, sendo referida também na Lei n ${ }^{\circ}$ 9882/99 - a primeira trata da Ação Direta de Inconstitucionalidade (ADI) e da Ação Declaratória de Constitucionalidade (ADC) e, a segunda, da Arguição de Descumprimento de Preceito Fundamental (ADPF). Com isso, estabeleceu-se a previsão de realização de APs no âmbito do exercício do controle concentrado de constitucionalidade, por convocação do presidente da corte ou do relator do processo e com a participação de membros da sociedade civil, para fins de esclarecimento de matéria ou circunstância de fato. A mesma legislação introduziu a figura do amicus curiae, na qualidade de representante da sociedade civil, interveniente no processo, ampliando ainda mais as possibilidades de interlocução entre Estado e sociedade civil na jurisdição constitucional.

Apesar de legalmente prevista desde 1999, a efetiva realização de uma audiência pública pelo STF é mais recente: data de 2007 e ocorreu no âmbito do julgamento da constitucionalidade da Lei de Biossegurança, que previa pesquisas com células-tronco embrionárias. Depois disso, as APs foram estendidas para outros processos, o que impulsionou o emendamento do Regimento Interno do STF, para, com base no artigo 13, inciso XVII, possibilitar a convocação de audiência pública para "ouvir o depoimento de pessoas com experiência e autoridade em determinada matéria, sempre que entender necessário o esclarecimento de questões ou circunstâncias de fato, com repercussão geral e de interesse público relevante, debatidas no âmbito do tribunal".

Desde então, a corte realizou audiências públicas sobre os mais diversos temas, tanto em sede de ADIs e ADPFs, quanto em sede de Recurso Extraordinário (RE). Precisamente, entre 2007 e 2014, o STF realizou 16 audiências públicas. Com exceção de uma - que versou sobre a importação de pneus 
11 A audiência pública sobre importação de pneus usados não foi incluída na análise pela impossibilidade de acesso aos dados (STF s.d.).

${ }^{12}$ No Brasil, é o caso Lei de Licitações e Contratos (Lei n ${ }^{\circ}$ 8.666/1993, Art. 39), em se tratando de licitações de grande vulto, do Estatuto das Cidades (Lei no 10.257/2001, Art. $\left.2^{\circ}, \mathrm{XIII}\right)$, entre outros.

13 Marona \& Rocha 2014; Vestena 2012; Ajouz \& Almeida 2013; Pessoa 2012; Lima 2008; Fragale Filho 2015; Naves 2012; Barbosa \& Pamplona 2011; Ariede 2011; Leite 2015. usados - todas as demais se encontram parcial ou totalmente documentadas no portal do tribunal ${ }^{11}$. Nesse contexto, as audiências públicas têm se tornado objeto de interesse científico. Os estudos destacam a variedade de formas e motivos pelos quais as APs podem ser empregadas: no contexto de um único processo decisório, ou de forma continuada; como forma de vocalização de preferências de múltiplos atores, resolução de conflitos e construção de consensos; como meio para informar o público-alvo sobre programas e projetos, seus objetivos e impactos (sem que este público possa influenciar o processo de tomada de decisão, ocorrido em momento anterior); para instruir aqueles que deverão tomar uma decisão em momento posterior; para aportar informação ao longo do processo decisório, ouvindo a todos os interessados e ampliando o rol de perspectivas e o leque de interesses considerados (combinando o conhecimento de autoridades públicas, especialistas, gestores e público-alvo). Em alguns casos, a realização de audiência pública está prevista legalmente constando como etapa obrigatória no processo de tomada de decisões ${ }^{12}$, em outros, a decisão de realizar a AP é discricionariedade das autoridades em questão (Souza \& Jacobi 2011).

Destaca-se, no âmbito desses estudos, o esforço para o estabelecimento de critérios de avaliação do funcionamento das audiências públicas em vista dos potenciais associados a elas (Fiorino 1990) e para a identificação de possíveis vieses e limitações. Quanto a este último aspecto, alguns autores chamam a atenção para o perfil dos participantes e a forma como este revela certas barreiras e filtros à entrada; o grau de representatividade dos participantes em face dos públicos em nome dos quais eles se apresentam como porta-vozes; as assimetrias de informação que marcam a participação dos atores, sobretudo nos casos em que há forte presença de especialistas ou a discussão se dá em torno de temas com forte caráter técnico e científico (Dietz, Stern \& Rycroft 1989; Topal 2009).

Particularmente sobre o impacto das audiências públicas no controle concentrado de constitucionalidade no Brasil também já foram produzidas algumas análises; geralmente veiculadas no campo jurídico e adstritas ao tratamento das APs ora como consequência, ora como elemento que vem impulsionando o que se convencionou chamar de judicialização da política ${ }^{13}$. Na maioria dos casos, o mecanismo é associado à busca de legitimação das decisões do STF e com a introdução de um elemento participativo com potencial de ampliar o diálogo da corte com a sociedade.

As análises consistem em estudos de um ou poucos casos com parcos esforços comparativos e, em geral, se valem de técnicas de análise documental e de discurso. Em suas conclusões, vários autores destacam que o poder dos ministros de delimitar e selecionar livremente o universo de participantes da AP e de definir as suas formas de intervenção limitam o alcance da inovação e dão aos ministros um papel central na construção do sentido da participação social no controle de constitucionalidade (Naves 2012; Marona \& Rocha 2014). Pesquisadores que realizaram um cotejamento entre o conteúdo da audiência pública (Marona \& Rocha 2014; Fragale Filho 2015; Vestena 2012) e a decisão final da corte destacam o subaproveitamento das APs na elaboração dos votos, o que estaria associado à tímida participação dos ministros nos eventos. Por outro lado, também é possível encontrar análises mais otimistas que chamam a atenção para alguns avanços no uso das APs, sobretudo em relação ao aporte informacional dado ao processo (Ajouz \& Almeida 2013; Ariede 2011). De toda forma, há um consenso em torno da necessidade de aperfeiçoamento para reduzir a distância entre o discurso oficial e a prática.

$\mathrm{O}$ aspecto original do presente artigo consiste, justamente, na articulação que propõe entre o objeto da análise e as discussões centrais em diferentes 
subcampos da teoria política para pensar a introdução de uma dimensão participativo-deliberativa no controle concentrado de constitucionalidade no Brasil. Além disso, objetiva-se oferecer um tratamento mais sistemático ao tema, abordando um número maior de casos. Na próxima seção apresenta-se um panorama das audiências públicas realizadas entre os anos de 2007 e 2014 pelo STF. A caracterização das APs e a sua análise em perspectiva comparada envolvendo regras, temas, atores, formatos e dinâmica - possibilitou avançar na compreensão do seu caráter e função no decision making e verificar em que medida essa inovação institucional têm ampliado a base informacional da tomada de decisões dos ministros e fomentado o diálogo e a interface entre atores societais e estatais ao permitir a inclusão e a incorporação de novos atores, interesses e perspectivas na dinâmica deliberativa. A análise permitiu, além disso, identificar os elementos comuns aos eventos, suas singularidades, as alterações ao longo do tempo, alguns avanços e os limites no que se refere ao uso que a corte vem realizando do instrumento.

\section{As audiências públicas do STF}

${ }^{14}$ As audiências públicas do STF são reguladas pelo Art. $9^{\circ}, \S 1^{\circ}$, da Lei $n^{\circ} 9.868 / 99$; art. $6^{\circ}, \S 1^{\circ}$, da Lei $n^{\circ}$ 9.882/99; e arts. 13, XVII, 21, XVII, e parágrafo único do art. 154 do Regimento Interno do STF.
As audiências públicas podem ser caracterizadas como uma variação das chamadas interfaces socioestatais - um espaço político estabelecido intencionalmente entre atores, cujos resultados podem gerar tanto implicações coletivas, quanto estritamente individuais (Isunza \& De La Jara 2006). Seriam “encontros públicos presenciais, promovidos pelo governo em torno de temáticas específicas, com o objetivo de discutir aspectos concernentes a uma determinada política, sendo aberta à participação dos indivíduos e grupos interessados" (Pires \& Vaz 2012, p.13). No entanto, as audiências públicas que ocorrem no Supremo possuem características próprias, que devem ser consideradas.

Apesar de existir, desde 1999, previsão legal para a realização de APs no âmbito da jurisdição constitucional, quando, em 2007, o STF de fato realizou a primeira audiência pública, não havia norma regimental que dispusesse sobre o procedimento a ser adotado. Por essa razão, como esclarecido pelo relator na ocasião, Ministro Ayres Brito, foram adotados os parâmetros do Regimento Interno da Câmara dos Deputados. Conforme já mencionado, apenas em 2009, por meio da Emenda Regimental n ${ }^{\circ} 29$, passou a constar no Regimento Interno do Supremo Tribunal Federal (RISTF) disciplina acerca da realização das APs $^{14}$.

A determinação regimental é sintética e se restringe ao estabelecimento da competência do presidente da corte ou do relator do processo decisório para convocar a AP, estabelecendo que deverá ser garantida a participação das diversas correntes de opinião e atribuindo ao ministro relator a competência para selecionar as pessoas que serão ouvidas, divulgar a lista dos habilitados, determinar a ordem dos trabalhos e fixar o tempo de que cada um disporá para se manifestar (RISTF, art. 154, parágrafo único, III). Também por determinação regimental, todas as APs devem ser transmitidas pela TV e pela Rádio Justiça, podendo ser veiculadas também por outras transmissoras que o requererem - fato que é reiteradamente destacado pelos ministros relatores ao longo das audiências.

Observa-se, portanto, que o formato da AP pode variar considerando a ampla liberdade que o relator tem para definir não somente quem participará, mas também as regras de interação entre os expositores. Genericamente, contudo, há procedimentos formais, regras que envolvem a formalização da AP (data e hora definidas, pauta clara, atas das sessões, gravação em vídeo e/ou voz), e a condução do debate (determinação de quais atores possuem a palavra, seu tempo de fala, dinâmica da interação). 
${ }^{15}$ Em 2015, foram realizadas duas APs não incluídas nesta análise: uma convocada pelo ministro Luís Roberto Barroso para discutir os modelos de ensino religioso em escolas públicas, e a outra, convocada pelo ministro Gilmar Mendes, para tratar do "uso de depósito judicial”.
No que diz respeito à incidência geral das audiências públicas na jurisdição constitucional, pode-se dizer que o uso desse mecanismo institucional vem se intensificando ao longo dos anos, não apenas no âmbito das ações constitucionais - casos em que o STF atua como corte constitucional, propriamente mas, também, quando atua como instância recursal do poder Judiciário, embora globalmente ainda seja um recurso de exceção. Ao longo dos anos a utilização das APs tornou-se mais frequente: se nos cinco primeiros anos (de 2007 a 2011) realizaram-se cinco APs, nos últimos dois anos, já foram realizadas nove, com destaque para o ano de 2013, quando foram realizadas sete audiências públicas $^{15}$. A Tabela 1 permite que se visualize a evolução na utilização do mecanismo no âmbito da jurisdição constitucional, considerando os controles de tipo difuso (RE) e concentrado (ADI, ADO, ADC, ADPF).

Percebe-se já a primeira característica definidora das APs: elas possuem um caráter pontual; quando se considera o total de processos que chegam ao STF, e, destes, o total que envolve o controle de constitucionalidade - seja em sede de recurso extraordinário, seja pelo julgamento de ações diretas - nota-se que o recurso à audiência pública é uma exceção, provavelmente mobilizado para a resolução de casos considerados mais complexos e controversos pela corte.

Isso, contudo, não desqualifica o mecanismo como importante objeto de análise para a compreensão da dinâmica de atuação do STF diante dos desafios e impasses atuais da democracia brasileira (Avritzer 2016), particularmente porque as questões que envolvem a realização das APs não são apenas complexas, do ponto de vista jurídico, mas impactam de forma importante a agenda pública nacional. Basta que se mencione pelos menos duas APs - pesquisas com célula-tronco embrionárias e aborto em caso de anencefalia - que envolveram o debate em torno do "direito à vida" que extrapola as fronteiras da dogmática constitucional e se encontra com os discursos (e lutas) mais contemporâneos do feminismo.

Vale lembrar também que o STF realizou audiência pública em meio à disputa em torno do "Mais Médicos" - um dos principais programas do governo federal na área de saúde. Ainda na área da saúde, outras duas APs foram convocadas, para que diretamente fossem debatidos aspectos da política pública nesse campo, particularmente relacionados com o Sistema Único de Saúde (SUS). A ação afirmativa racial, que previa reserva de vagas no ensino público superior, também não escapou das considerações do STF e, mais uma vez, uma AP foi convocada. Ademais, questões ambientais foram objeto de escrutínio no

Tabela 1 - Ações Constitucionais relacionadas ao controle concentrado (ADI, ADO, ADC, ADPF), Recursos Extraordinários (REs) e APs realizadas no STF (2007-2014)

\begin{tabular}{lcccc}
\hline Ano & $\begin{array}{c}\text { Processos } \\
\text { distribuídos }\end{array}$ & $\begin{array}{c}\text { Recursos } \\
\text { Extraordinários }\end{array}$ & $\begin{array}{c}\text { Controle Concentrado } \\
\text { (ADI, ADPF, ADC, ADO) }\end{array}$ & APs realizadas \\
\hline 2007 & 112.938 & $49.708(44,0)$ & $88(0,08)$ & 1 \\
2008 & 66.873 & $21.531(32,2)$ & $114(0,17)$ & 2 \\
2009 & 42.729 & $8.348(19,5)$ & $223(0,52)$ & 1 \\
2010 & 41.014 & $6.735(16,4)$ & $155(0,38)$ & 1 \\
2011 & 38.109 & $6.388(16,8)$ & $196(0,51)$ & 0 \\
2012 & 46.392 & $6.042(13,0)$ & $203(0,43)$ & 2 \\
2013 & 27.528 & $3.805(13,8)$ & $223(0,81)$ & 6 \\
2014 & 57.799 & $9.671(16,7)$ & $131(0,22)$ & 2 \\
Total no período & 433.382 & $112.228(25,9)$ & $1333(0,30)$ & 15 \\
\hline
\end{tabular}

Fonte: As autoras. 
âmbito de ações constitucionais que mereceram a realização de APs: importação de pneus usados, campo eletromagnético, queimadas e proibição do uso de amianto. Por fim, realizou-se AP no âmbito da ação constitucional que tratava do sistema de financiamento de campanhas no Brasil, aspecto central de disputa política no contexto democrático atual.

Por outro lado, as APs realizadas até o momento variaram tanto em relação ao tipo de controle de constitucionalidade - pelo menos seis delas foram realizadas em processos nos quais o STF atua em sede recursal (Recursos Extraordinários - REs), vinculados, portanto, ao controle difuso de constitucionalidade - quanto no que diz respeito aos autores/recorrentes. A Tabela 2 permite visualizar essa variação.

Os autores/recorrentes foram agrupados em duas categorias: atores estatais e entidades representativas. Essas categorias foram construídas em observância, particularmente, ao amplo rol de legitimados para a propositura das ações diretas, inscrito no art. 103 da Constituição de 1988. Desse modo, foram considerados os seguintes atores estatais: a Presidência da República, os governadores de estados, as mesas do Senado Federal, da Câmara de Deputados e das Assembleias Legislativas, e o Ministério Público. Foram incluídos, dentre os atores estatais, também aqueles órgãos ou instituições que figuraram como recorrentes, em sede de controle difuso de constitucionalidade. Dentre as entidades representativas da sociedade foram incluídos os partidos políticos, os sindicatos, as entidades de representação de classe e outras associações civis legitimadas para a propositura de ações diretas de constitucionalidade.

Observa-se, assim, que no âmbito do controle concentrado, as APs foram realizadas, em sua maioria, em ações de autoria de entidades representativas da sociedade. Inverte-se essa relação quando se observa o universo de recursos extraordinários: nesse caso, que se vincula ao controle difuso de constitucionalidade, as APs realizadas envolviam recursos de autoria de entes estatais. Isso pode sugerir que as APs cumprem com finalidades distintas em um e outro caso. Quando se trata de controle concentrado de constitucionalidade, em que o impacto da decisão judicial é mais potente em termos sociais, econômicos e políticos, as APs podem funcionar como um espaço de mediação entre o Estado e a sociedade, configurando-se como um ponto de interface socioestatal.

Por outro lado, quando o STF é chamado a se manifestar em sede de recurso, que veicula uma demanda muito mais concreta, entre duas partes, as APs podem funcionar como propulsoras de um diálogo interinstitucional (Mendes 2013), um espaço de diálogo entre os poderes do estado. Neste último caso, destaca-se a AP realizada em 2009, com relatoria do Ministro Gilmar Mendes, a partir da reunião de vários pedidos de suspensão (de liminar e de tutela antecipada) que tratam do direito à saúde (internação em unidade de tratamento intensivo,

Tabela 2 - Autoria dos feitos judiciais em que foram realizadas APs por categoria de ator e tipo de controle de constitucionalidade (2007-2014)

\begin{tabular}{lcc}
\hline Tipo de Controle & \multicolumn{2}{c}{ Autoria } \\
\cline { 2 - 3 } & Estado & Sociedade \\
\hline Controle Concentrado & 3 & 12 \\
Recurso Extraordinário & 13 & 1 \\
Total $^{\mathrm{I}}$ & 16 & 13 \\
\hline
\end{tabular}

Fonte: As autoras.

${ }^{\mathrm{I}} \mathrm{O}$ total das ações não é igual ao total das APs porque em três APs os ministros agruparam mais de uma ação. 
${ }^{16}$ Vale a pena destacar que a AP realizada em junho de 2015 foi convocada pelo Ministro Barroso que, curiosamente, atuou como advogado de entidade civil, interveniente no processo em que se realizou a primeira AP no STF, em 2007. fornecimento de medicamento etc.), questão recorrente e objeto, inclusive, de uma proposta de súmula vinculante $\left(\mathrm{n}^{\circ} 4\right)$ e um recurso extraordinário $\left(\mathrm{RE} \mathrm{n}^{\mathrm{o}}\right.$ 566.471), com repercussão geral reconhecida, a envolver a eficácia do artigo 196 da Constituição.

Conforme mencionado, as APs realizadas pelo STF trataram dos mais diversos assuntos, tais como direito à vida, proteção ao consumidor, princípio da isonomia, liberdade econômica e livre-iniciativa, direito à saúde, dignidade da vida e da saúde do trabalhador, defesa do meio ambiente, entre outros. Os eventos foram convocadas por diversos ministros. Desde que se realizou a primeira AP, em abril de 2007, o STF já alterou a sua composição sete vezes. Ao todo, atuaram na corte entre 2007 e 2014, dezessete ministros. Destes, sete convocaram audiências públicas: Ayres Britto e Ricardo Lewandowski convocaram uma, cada um; Gilmar Medes, Carmen Lúcia e Dias Toffoli convocaram duas, cada um; Marco Aurélio Mello convocou três e Luiz Fux convocou cinco audiências públicas, ainda que tenha tomado posse apenas em $2011^{16}$. Considerando que os relatores têm discricionariedade para decidir quando convocar ou não uma $\mathrm{AP}$, podemos supor que alguns ministros tenham maior simpatia à novidade institucional do que outros, particularmente quando se observa tamanha variação no tocante ao tipo de controle de constitucionalidade no âmbito do qual as APs foram realizadas, às temáticas envolvidas e aos tipos de autores/recorrentes, como forma de aferir os interesses do estado e da sociedade.

A compreensão de quando e porque o relator decide convocar uma AP dependeria de uma análise que vai além do esforço realizado neste artigo. É possível, contudo, a partir das razões para convocação das APs, expressas nos competentes editais (STF s.d.), e considerando também as manifestações dos ministros ao longo de todo o processo, apontar um padrão relevante. As razões expressas nos editais de convocação remetem ora à qualidade da questão envolvida, destacando sua relevância (jurídica, econômica e social) e natureza controversa, ora ao potencial da própria AP para aplacar os desafios impostos pela construção de uma decisão que é fundamental e envolve um debate que suscita "enfoques diversificados", numerosos questionamentos, múltiplos entendimentos e várias controvérsias.

Foram três as justificativas mais mobilizadas nos editais: (1) o fato de o tema a ser debatido ultrapassar "os limites do estritamente jurídico", e demandar "abordagem técnica e interdisciplinar da matéria" para "esclarecimento das questões de fato pertinentes ao caso" e para municiar a corte de informações e subsidiar sua decisão; (2) a necessidade de conhecer e prognosticar as consequências, implicações e repercussões práticas (administrativas, econômicas e sociais) da legislação discutida; e (3) o fato de a legislação ou questão discutida apresentar importantes impactos sobre determinados grupos ou, o oposto, não se restringir a interesses específicos do autor ou autores da ação repercutindo em valores fundamentais dos indivíduos e da sociedade brasileira.

Associado ao reconhecimento do potencial informacional das APs, em três dos 15 casos analisados, os editais de convocação são explícitos quanto aos ganhos de legitimidade esperados com a realização do evento. Um deles destaca ser "valiosa e necessária a realização de Audiência Pública" para que a "corte possa ser municiada de informações imprescindíveis para o deslinde do feito, bem como para que o futuro pronunciamento judicial revista-se de maior legitimidade democrática"; em outro, o relator afirma que a AP possibilitará "uma maior participação da sociedade civil no enfrentamento da controvérsia constitucional, o que certamente legitimará ainda mais a decisão a ser tomada pelo Plenário" (Editais de convocação das APs sobre Alterações no marco regulatório da gestão coletiva de direitos autorais no Brasil, Realização de 
17 As duas audiências em questão versavam sobre Campo eletromagnético de linhas de transmissão de energia e Internação hospitalar com diferença de classe no SUS. pesquisas com células-tronco embrionárias e Financiamento de campanhas eleitorais) (STF s.d.).

O discurso da ampliação da legitimidade democrática da decisão, associado ao ganho informacional que a AP promove, é recorrente nas manifestações dos ministros ao longo das audiências. Das oito audiências para as quais tivemos acesso à íntegra dos debates, apenas em duas - ambas relatadas pelo ministro Dias Toffoli - não foi feita menção aos potenciais ganhos de legitimidade do evento para as decisões da corte e nem referências à importância da participação da sociedade ${ }^{17}$. Nas demais, as falas de abertura e de encerramento funcionaram como um momento de reflexão em torno da AP, particularmente em relação aos seus objetivos, às expectativas associadas à sua realização e ao seu significado, seja para o STF, seja para a democracia brasileira.

Não ignoramos o fato de estarmos lidando com o discurso oficial de representantes do órgão máximo da justiça brasileira que não expressam a forma como as audiências públicas têm sido conduzidas e seus reais impactos sobre o processo de tomada de decisões na corte. Consideramos que, assim como todos os mecanismos, canais e inovações participativas, formais e informais, que abundam no âmbito da sociedade civil e dos poderes Legislativo e Executivo, o instrumento incorporado ao controle concentrado de constitucionalidade e seus usos devem ser avaliados em sua operação efetiva e em sua capacidade real de fomentar participação, deliberação, inclusão e diálogo. A incorporação, na análise, de algumas falas dos ministros é válida, apenas, para apontar possíveis incongruências entre seu discurso oficial e o uso efetivo do instrumento ou, mesmo, revelar a maior ou menor abertura dos ministros em relação a esta novidade institucional.

A referência direta ao fato de que as audiências contribuem para ampliar a legitimidade das decisões da corte abunda nas falas dos ministros Ricardo Lewandowski, Ayres Britto, Gilmar Mendes e Luiz Fux. A noção de participação popular, de ouvir "o povo", "a sociedade" é bastante mobilizada também por representantes do Ministério Público, presentes nas seções, e por muitos daqueles que participavam como expositores. Particularmente, três ministros destacaram que as APs do STF seriam um desdobramento, senão uma culminância, de princípios consagrados pela Constituição de 1988, a saber, a garantia de maior participação dos cidadãos e da sociedade organizada no processo de tomada de decisões. As palavras dos ministros sugerem que, com a introdução das APs na dinâmica decisória do STF, a corte estaria acompanhando uma tendência já presente no âmbito do Executivo e do Legislativo.

A percepção dos ministros - e expositores - acerca do potencial das audiências públicas no âmbito da jurisdição constitucional parece se fundamentar em um tripé conceitual: legitimidade, participação e informação. A legitimidade democrática do processo decisório se aprofunda pela participação que as audiências públicas promovem, na medida em que se produzem decisões mais bem informadas, considerando não apenas a complexidade técnica das questões envolvidas, mas também o pluralismo moral e as múltiplas perspectivas políticas presentes em sociedade. As falas reproduzidas a seguir são elucidativas no que se refere ao aporte informacional que se espera que as audiências ofereçam ao processo de decisão.

"É um aprendizado para todos nós cada vez que realizamos essas audiências públicas tão complexas e tão fascinantes. Também é uma atitude de humildade e de modéstia do Tribunal que busca auscultar os mais diversos setores para ter uma decisão devidamente informada" (Ministro Gilmar Mendes in STF 2008, p.68).

"Essas quatro sessões desta Audiência Pública demonstraram o quão necessário, o quão importante é a ouvida de tantos segmentos. E que certamente a corte, por mais sábios que sejam os seus integrantes, não teria condições de aferir ou de 
${ }^{18}$ Em alguns casos, havendo superlotação do local, o Tribunal disponibiliza uma segunda sala para alocar os participantes com transmissão simultânea da AP por meio de telões.

${ }^{19}$ O portal do STF disponibiliza, para algumas audiências públicas, textos, documentos e sugestões enviados por instituições e organizações sociais interessadas no tema.
${ }^{20}$ Como só obtivemos acesso às notas taquigráficas de 8 das 15 audiências, este número pode não ser exato considerando-se que existem discrepâncias entre a programação e as notas taquigráficas em função de mudanças, desistências, faltas e substituições de última hora.

${ }^{21}$ Neste primeiro momento, optamos por não distinguir esses tipos, mas entendemos tratar-se de uma tarefa de crucial importância para que possamos avançar no coletar tantos dados de tantas diferentes posições que foram trazidas aqui" (Mario José Gisi in STF 2008, p.73).

Evidencia-se, aí, outra característica das audiências públicas: elas possuem um caráter consultivo, pois abrem a possibilidade para que segmentos da sociedade possam se expressar e propor soluções, embora caiba aos ministros acatar ou não as propostas. Abre-se a possibilidade de rompimento de um paradigma, na medida em que são borradas as fronteiras entre o conhecimento jurídico e os valores políticos que, eventualmente, o informam. O potencial informacional das APs, reconhecido pelos ministros e representantes em seu discurso oficial, pode e deve, no entanto, ser qualificado. Em grande medida, sua efetividade depende do tipo de inclusão que a AP promove, do formato da interação e, mais importante, da conexão entre a AP e a decisão final dos ministros.

Cada vez que uma AP é convocada a corte divulga em seu sítio eletrônico uma síntese das regras de participação. Existem três modalidades de participação: (1) como parte da plateia sem direito a qualquer manifestação; (2) enviando sugestões; e (3) como expositor na audiência, caso em que é necessária inscrição prévia e deferimento pelo relator. No primeiro caso, o limite para participação é a capacidade do local de realização ${ }^{18}$ e os lugares são ocupados por ordem de chegada, respeitada a reserva aos expositores e à imprensa. No segundo caso, admite-se que qualquer pessoa ou entidade, independentemente de inscrição, encaminhe documentos úteis ao esclarecimento das questões a serem debatidas na AP, pela via impressa ou eletrônica ${ }^{19}$. O terceiro e mais importante caso versa sobre os expositores da AP, os quais são indicados pelas partes do processo, por órgãos e entes estatais e entidades da sociedade civil ou pelos interessados que requerem sua participação (especialistas habilitados). As entidades interessadas em indicar especialistas e os amici curiae devem se inscrever para participar da audiência no prazo estipulado pelo edital de convocação. O requerimento de inscrição como expositor deve ser acompanhado do currículo do especialista, do resumo da tese e da posição a ser defendida.

Destacam-se aqui outras características das APs, considerando, particularmente as regras de participação dos expositores. As APs possuem um caráter presencial, ou seja, não podem ser realizadas pela internet e permitem um intercâmbio documental bastante restrito, privilegiando a manifestação oral dos participantes. Ademais, embora seja possível a participação de atores individuais - especialmente como expectadores - privilegia-se a participação de caráter coletivo.

Nas 15 audiências públicas para as quais obtivemos acesso às informações sobre os admitidos, verificamos um total de 398 participantes que se encaixam na categoria de expositores, isto é, participantes que puderam defender seus pontos de vista ou das instituições que representavam durante o evento ${ }^{20}$. Os expositores podem ser classificados de acordo com a origem da sua indicação. Além da categoria mais evidente, que reúne os agentes estatais, indicados por um dos três poderes da república, ou o representante do Ministério Público, a categoria "sociedade civil" contempla associações profissionais, entidades de classe, sociedades médicas, movimentos sociais, frentes, conselhos de políticas públicas, associações de tipos e formas de organização variadas voltadas para a ajuda mútua e defesa de causas $^{21}$. Ademais, a categoria dos especialistas foi elaborada para abrigar os expositores que não se apresentavam como "falando em nome de" ou expondo uma posição oficial das instituições e entidades das quais faziam parte (ainda que ocupassem cargos de relevo em seu interior). Nesse caso, a participação se amparou na expertise acumulada pelo expositor, seja como estudioso ou pesquisador do tema debatido, seja como ocupante de cargos em instituições importantes na área. Foram incluídos nesta categoria 
entendimento de quão inclusivas têm sido as APs.

22 Conscientes de que esta classificação pode ser questionada porque encerra algumas ambiguidades, as autoras optaram por considerar representantes de instituições somente aqueles que assim se apresentaram explicitamente. renomados cientistas de diversas áreas do conhecimento, ocupantes e ex-ocupantes de cargos e posições de relevo e trabalhadores manuais que acumularam conhecimentos sobre o assunto debatido, caso em que a sua expertise estava mais associada a um testemunho validado por muitos anos de trabalho ou militância em prol de uma determinada questão ${ }^{22}$. A categoria "outros" corresponde, por fim, a casos de difícil classificação em função da ausência de informações detalhadas sobre o expositor e sua instituição.

O número de expositores variou de 14 a 42 , resultando em uma média de 26,5 por AP. Não dispomos de informações suficientes para compreender essa variação; a melhor hipótese é a de que ela esteja relacionada ao grau de controvérsia envolvida e ao número de pessoas que solicitaram participação junto ao STF bem como à disponibilidade do relator para presidir o evento por mais de um dia. O Gráfico 1 permite afirmar, no entanto, que há uma maior participação, em termos quantitativos, de expositores indicados por associações ou coletivos da sociedade civil: as organizações sociais representam $37 \%$ do total de participantes, seguida dos especialistas que correspondem a $30 \%$.

Entre os poderes do Estado, o Executivo tem a presença de maior constância, estando ausente apenas da primeira AP, realizada no ano de 2007. Representantes do Legislativo estiveram presentes em 10 das 15 audiências analisadas. Dos 20 membros do Poder Legislativo presentes nas audiências, 13 eram membros da Câmara dos Deputados e 4 do Senado (os demais eram membros dos legislativos estaduais ou municipais). Em vários casos, os parlamentares que participaram das APs tinham sido ou autores das leis debatidas ou relatores de projetos de lei relacionados ao tema. A participação do Judiciário é discreta e coerente com o objetivo da audiência que é de buscar contribuições interdisciplinares, para além do campo jurídico. $\mathrm{O}$ mesmo se pode dizer em relação ao Ministério Público, com a ressalva de que seus representantes geralmente podem participar como convidados das APs.

Em relação à esfera de atuação, é claro o predomínio de representantes de instituições situadas no nível nacional (esta classificação só foi feita para os poderes do Estado e para a categoria sociedade civil, não se aplicando aos especialistas). Dos 214 participantes para os quais foi possível identificar a esfera de atuação de sua respectiva instituição, 143 ou 67\% atuavam no nível nacional, seguidos por 63 (29,3\%) representantes de órgãos e instituições de abrangência estadual e de apenas $8(3,7 \%)$ da esfera municipal.

Gráfico 1 - Participantes das audiências públicas do STF por modalidade (2007-2014)

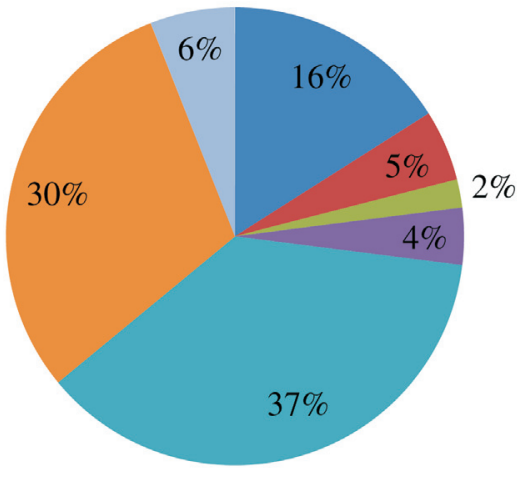

Executivo

- Legislativo

- Judiciário

n Ministério Público

- Sociedade civil

- Especialistas

- Outros

Fonte: As autoras. 
${ }^{23}$ Infelizmente não foi possível ter acesso às informações sobre as participações indeferidas pelos relatores. A coleta desses dados integra a próxima etapa da investigação da pesquisa.

${ }^{24}$ Um perfil mais diversificado também pode ser observado na audiência que tratou das políticas de ação afirmativa (racial) de acesso ao Ensino Superior.
O predomínio de representantes de órgãos e instituições nacionais, tanto entre as instituições estatais quanto entre as organizações e entidades da sociedade civil, explica-se pela natureza - constitucional - das questões em debate. Além disso, relaciona-se à própria divisão constitucional de competências que coloca nas mãos do poder central a maior parte das responsabilidades e atribuições em uma ampla gama de temas e assuntos. Prova disso são as três exceções em que a presença de representantes de órgãos e entidades estaduais supera a de outras esferas: as audiências sobre "Queimadas em canaviais", "Lei Seca" e "Regime Prisional". Nos dois últimos casos, a questão central debatida na audiência está estreitamente associada, embora não apenas, ao tema da segurança pública, área de política que a Constituição reservou aos estados da federação. Por outro lado, é possível imaginar que tanto aqueles que indicam os participantes quanto o ministro relator tenham a preocupação de priorizar organizações sociais com maior representatividade por sua atuação em todo ou em boa parte do território nacional.

Os dados sugerem que o perfil dos participantes das audiências varia conforme a temática tratada, se relaciona com a distribuição de competências entre os entes federados e com a origem da ação que desencadeou o processo. Mas, certamente, aquele perfil também está associado às escolhas feitas pelas partes, responsáveis pela indicação dos expositores, e pelos ministros, responsáveis pelo deferimento e indeferimento das solicitações ${ }^{23}$. A comparação entre duas audiências que lidavam com temas correlatos ilustra bem esse fato.

Na primeira audiência realizada pelo STF sobre "Pesquisa com célulastronco embrionárias", as regras adotadas para a definição dos participantes induziram à restrição do conceito de sociedade civil, identificada com a comunidade científica, e, mais especificamente, com aquele grupo ligado às ciências médicas e biológicas (Marona \& Rocha 2014). Um ano depois, na audiência sobre "Interrupção de gravidez - Feto anencéfalo", observou-se uma ampliação da noção de sociedade civil com um claro predomínio de representantes de organizações da sociedade, resultando em uma participação mais diversificada que incluiu não somente as sociedades médicas, mas frentes, movimentos, organizações religiosas, organizações não governamentais etc ${ }^{24}$. Nos dois casos, a corte lidava com temas comparáveis e igualmente complexos e controversos (direito à vida, direito ao próprio corpo), mas, no segundo caso, foi além da intervenção dos experts possibilitando um debate público ampliado, nos termos apontados por Rosanvallon (2011).

A presença de membros de instituições e organizações dos três poderes e da sociedade civil atuantes nos três níveis de governo oferece evidências de que as APs estão funcionando como indutoras de um maior diálogo interinstitucional e como interface sócio-estatal de natureza consultiva, conectando atores, interesses, valores, discursos e argumentos. As falas de vários ministros mostram que existe uma expectativa quanto a este papel das APs, das quais se destacam, as dos ministros Lewandowki e Gilmar Mendes, respectivamente:

"[...] as audiências públicas realmente representam uma oportunidade que tem o Supremo Tribunal Federal de ouvir não apenas a sociedade civil de modo geral, mas os membros dos demais Poderes e também os especialistas nos assuntos" (Ministro Ricardo Lewandowski in STF 2010, pp.3-6).

"Quando estive aqui há uma semana, tive oportunidade de ressaltar a importância dessa prática que coloca a possibilidade de um diálogo efetivo entre o Tribunal e a comunidade científica, neste caso específico, mas de maneira geral entre o Tribunal e a sociedade de forma geral" (Ministro Gilmar Mendes in STF 2008, p.2).

Reconhecemos, porém, que uma melhor compreensão da qualidade e do caráter desse diálogo e dessa interface depende do emprego de outras estra- 
${ }^{25}$ Há, contudo, evidências de subaproveitamento das APs na elaboração dos votos dos ministros. Ver Marona e Rocha (2014); Fragale Filho (2015). tégias analíticas, tarefa a ser cumprida nas próximas etapas do projeto de investigação, cujos resultados parciais aqui apresentamos, conforme já apontado. Por ora, nos limitamos à análise do formato da audiência e da interação entre os participantes.

A Emenda Regimental № 29 de 2009, que regula a realização de audiências públicas no STF, reserva grande liberdade para o ministro relator, que pode decidir discricionariamente acerca das pessoas que serão ouvidas, a ordem dos trabalhos e o tempo reservado para cada expositor. Em geral, as APs começam com uma fala de abertura do relator, que cede a palavra para o representante do Ministério Público apresentar suas considerações. A partir daí, os expositores se manifestam um a um de acordo com a ordem previamente estabelecida.

Destaca-se, nesse ponto, o fato de que por reiteradas vezes os relatores exerceram algum tipo de controle sobre o conteúdo das exposições, afastando a necessidade de exposições tipicamente jurídicas - que deveriam ser objeto de sustentação oral em momento processual adequado - e incentivando o foco em "aspectos técnicos de áreas do conhecimento diversas" (STF s.d.). Assim, evidencia-se uma primeira limitação do uso que o STF faz das APs: os expositores não são inteiramente livres para incluir tópicos na agenda e tampouco dar-lhes o tratamento desejado.

Por outro lado, o tempo para as exposições foi distribuído igualmente entre os participantes e rigidamente observado em todas as audiências, ainda que existam variações importantes na forma de condução dos trabalhos. A duração das audiências variou de 1 a 6 dias, mas, na maior parte dos casos, ocorreu durante 1 ou 2 dias (conforme Quadro 1). Não existe uma relação direta e linear entre o número de expositores e o número de dias reservados para o evento. Algumas contaram com a participação de um mestre de cerimônias enquanto outras eram conduzidas apenas pelo relator. Em várias APs, os participantes fizeram uso de recursos audiovisuais (vídeos, depoimentos e slides).

Embora não seja o foco, neste artigo, o tratamento aprofundado da dimensão da deliberação, a análise da interação entre os expositores e entres estes e os ministros nos permitem uma aproximação em relação à questão. Uma das hipóteses de nosso projeto de investigação é a de que as APs realizadas pelo STF têm o potencial de qualificar o processo deliberativo interno, na própria AP e nos estágios finais do processo, no momento em que os ministros elaboram, apresentam e justificam seus votos ${ }^{25}$.

As primeiras evidências reunidas por nós, contudo, desencorajam a hipótese de que as APs possuam um forte caráter deliberativo, ainda que se adote um conceito enxuto de deliberação, sem todas as exigências frequentemente associadas ao procedimento e às arenas deliberativas. Isso porque as APs, da forma como tem sido empregadas no STF, limitam sobremaneira a interação entre os participantes, inviabilizando o intercâmbio regulado de razões com vistas à apresentação e à justificação de posições e à persuasão mútua.

Em quatro audiências públicas - metade dos casos para os quais tivemos acesso à íntegra das notas taquigráficas - as exposições se sucederam sem nenhuma intervenção ou apenas intervenções pontuais dos relatores; em apenas dois casos as exposições foram intercaladas por perguntas durante e ao final da audiência, revelando um formato um pouco menos rígido. Mais uma vez vale uma comparação entre as duas primeiras audiências realizadas pela corte pesquisas com células-tronco embrionárias e interrupção de gravidez/feto anencéfalo - cujas temáticas podem ser aproximadas em função da problemática que envolve a interpretação do caput do art. $5^{\circ}$ da Constituição de 1988. Ainda que nos dois casos não tenha sido permitido aos participantes dirigirem a palavra uns aos outros, no segundo (interrupção de gravidez/feto anecéfalo) a AP foi 
Quadro 1 - Regras e dinâmica das audiências públicas do STF (2007-2014)

\begin{tabular}{|c|c|c|c|}
\hline Audiência Pública & Duração (dias e horas) & N. de expositores & Tempo por expositor \\
\hline 1. Pesquisas com células-tronco embrionárias & 1 dia 5 horas & 22 & Sem informação ${ }^{I}$ \\
\hline 2. Interrupção de gravidez - Feto anencéfalo & 4 dias & 27 & $15 \mathrm{~min}$ \\
\hline 3. Judicialização do direito à saúde & 6 dias & 33 & Sem informação \\
\hline $\begin{array}{l}\text { 4. Políticas de ação afirmativa de acesso ao } \\
\text { ensino superior }\end{array}$ & 3 dias $10 \mathrm{~h}$ e $30 \mathrm{~min}$ & 42 & $15 \mathrm{~min}$ \\
\hline $\begin{array}{l}\text { 5. Lei Seca/Proibição da venda de bebidas } \\
\text { alcoólicas nas proximidades de rodovias }\end{array}$ & 2 dias $8 \mathrm{~h}$ & 24 & $15 \mathrm{~min}$ \\
\hline 6. Proibição do uso de amianto & 2 dias $12 h$ & 35 & $20 \mathrm{~min}$ \\
\hline $\begin{array}{l}\text { 7. Novo marco regulatório para a TV por } \\
\text { assinatura no Brasil }\end{array}$ & 2 dias & 30 & $15 \mathrm{~min}$ \\
\hline $\begin{array}{l}\text { 8. Campo Eletromagnético de Linhas de } \\
\text { Transmissão de Energia }\end{array}$ & 3 dias $9 \mathrm{~h}$ & 21 & $15 \mathrm{~min}$ \\
\hline 9. Queimadas em Canaviais & 1 dia $5 h$ & 26 & $10 \mathrm{~min}$ \\
\hline 10. Regime Prisional & 2 dias $9 h$ & 33 & $15 \mathrm{~min}$ \\
\hline 11. Financiamento de Campanhas Eleitorais & 2 dias $11 \mathrm{~h}$ & 28 & $15 \mathrm{~min}$ \\
\hline 12. Biografias não autorizadas & 1 dia $5 h$ & 17 & $15 \mathrm{~min}$ \\
\hline 13. Programa "Mais Médicos" & 2 dias $9 \mathrm{~h} \mathrm{e} 40 \mathrm{~min}$ & 22 & $20 \mathrm{~min}$ \\
\hline $\begin{array}{l}\text { 14. Alterações no marco regulatório da gestão } \\
\text { coletiva de direitos autorais no Brasil }\end{array}$ & $1 \mathrm{dia} 4 \mathrm{~h}$ e $50 \mathrm{~min}$ & 24 & $10 \mathrm{~min}$ \\
\hline $\begin{array}{l}\text { 15. Internação hospitalar com diferença de } \\
\text { classe no SUS }\end{array}$ & $1 \mathrm{dia}$ & 14 & $15 \mathrm{~min}$ \\
\hline
\end{tabular}

Fonte: As autoras.

I 1h30min na parte da manhã e 2h na parte da tarde para cada um dos dois blocos de opinião.

mais dinâmica: os expositores foram instados a responder a perguntas dos relatores e representantes das partes e houve abertura para perguntas (não previstas) de duas pessoas.

Na maior parte dos casos, entretanto, observa-se uma evidente limitação dos potenciais deliberativos do mecanismo quando se veda a interação entre os que falam e os tomadores de decisão. Para as oito APs para as quais tivemos acesso às notas taquigráficas, foi possível destacar quatro cenários diferentes sistematizados no Quadro 2 que organiza os casos do formato menos dinâmico para o mais dinâmico no que se refere à interação. Afirmações mais conclusivas, contudo, dependem da análise substantiva da interação e do conteúdo em todas as dezoito audiências realizadas desde 2007.

De modo geral, o formato das audiências faz com que elas se assemelhem mais a uma arguição do que a um debate propriamente dito. Em nenhum caso foi permitido aos participantes dirigirem a palavra uns aos outros sob o argumento de que se tratava de uma audiência de caráter instrutório e mesmo as menções de um expositor à fala ou argumentação de outro eram reguladas. Ainda assim, verificou-se certo intercâmbio indireto de ideias e troca de informações, pois os participantes pareciam já conhecer os principais argumentos uns dos outros e buscaram reforçá-los ou questioná-los com a apresentação de outros argumentos e evidências (Marona \& Rocha 2014).

No que se refere aos ganhos informacionais proporcionados pelas APs não resta nenhuma dúvida sobre seu potencial. Ao longo dos trabalhos, os participantes contribuíram para a abordagem do tema a partir de diversas perspectivas. Verificou-se a ampliação do volume, da variedade e da qualidade da informa- 
Quadro 2 - Cenários de interação nas APs (2007-2014)

\begin{tabular}{|c|c|}
\hline Cenário & $\mathbf{A P s}^{\mathrm{I}}$ \\
\hline $\begin{array}{l}\text { (1) Apresentação dos expositores, sem intervenções durante } \\
\text { ou ao final da audiência. }\end{array}$ & $\begin{array}{l}\text { Novo marco regulatório para a TV por assinatura no Brasil, } \\
\text { Financiamento de Campanhas Eleitorais e Políticas de ação } \\
\text { afirmativa de acesso ao ensino superior. }\end{array}$ \\
\hline $\begin{array}{l}\text { (2) Apresentação dos expositores, sem intervenções durante } \\
\text { ou ao final da audiência. Perguntas dos ministros ao final. }\end{array}$ & Pesquisas com células-tronco embrionárias \\
\hline $\begin{array}{l}\text { (3) Apresentação dos expositores, com intervenções pontuais } \\
\text { para pergunta/esclarecimento do representante do MP ou do } \\
\text { relator. }\end{array}$ & $\begin{array}{l}\text { Queimadas em Canaviais e Internação hospitalar com } \\
\text { diferença de classe no SUS }\end{array}$ \\
\hline $\begin{array}{l}\text { (4) Apresentação dos expositores, com possibilidade de } \\
\text { intervenção do representante do MP, advogado da arguente e } \\
\text { relator ao final de cada exposição para perguntas e } \\
\text { esclarecimentos. }\end{array}$ & $\begin{array}{l}\text { Campo Eletromagnético de Linhas de Transmissão de } \\
\text { Energia e Interrupção de gravidez - Feto anencéfalo }\end{array}$ \\
\hline
\end{tabular}

Fonte: As autoras.

I No caso da AP sobre "Políticas de ação afirmativa de acesso ao ensino superior", ao final, o relator permitiu a manifestação de dois estudantes que solicitaram a palavra. No caso da AP sobre "Interrupção de gravidez - Feto anencéfalo", um expositor e um membro da plateia puderam fazer perguntas.

ção, em consonância com o objetivo do STF ao aderir ao mecanismo. As exposições não se restringiram ao tradicional domínio jurídico, estendendo-se a questões técnicas e interdisciplinares e resultando em rico material para subsidiar a decisão da corte no que diz respeito aos possíveis prognósticos em relação às consequências, implicações e repercussões práticas da legislação discutida, impactos específicos sobre determinados grupos ou acertos em relação a valores fundamentais dos indivíduos e da sociedade brasileira.

A efetividade do aporte informacional, contudo, depende do grau em que essas informações são consideradas e incorporadas aos votos dos ministros, no momento posterior da decisão. Não foi objetivo, nesta etapa da investigação, cotejar o conteúdo das audiências com os votos dos ministros, mas esta, certamente, é uma tarefa crucial para se avançar na compreensão do papel e dos impactos das APs. Discordamos, porém, que este aspecto - impacto das APs no resultado final - deva ser considerado o único indicador ou critério para a avaliação do instrumento. Em alguma medida, a realização da audiência pública e a inclusão de múltiplos interesses e pontos de vista, independentemente do resultado, podem surtir efeitos benéficos em termos de legitimidade aos olhos dos participantes e dos grupos que estes representam.

\section{Conclusões}

Este artigo se insere no conjunto de análises que conformam a agenda de pesquisa em torno do fenômeno da judicializacão da política no Brasil, considerando, fundamentalmente, a atuação do Supremo Tribunal Federal, particularmente no exercício do controle de constitucionalidade das leis e atos normativos. A perspectiva analítica empreendida resgata a preocupação com a legitimidade democrática das cortes constitucionais, remetida, aqui, à reconstrução do embate teórico acerca da natureza das relações entre constitucionalismo e democracia. O objeto de análise - as audiências públicas no Supremo Tribunal Federal - foi considerado, portanto, como uma particular oportunidade de compreensão acerca do potencial do Supremo Tribunal Federal para ativar a dimensão reflexiva da legitimidade democrática com a introdução de um elemento participativo-deliberativo no controle concentrado de constitucionalidade.

A crítica e necessária reavaliação do modelo de representação que se tornou hegemônico no Ocidente e que, em princípio, negava ao Judiciário qualquer 
papel relevante em termos do exercício da representação política, vê-se adensada em face do protagonismo das cortes constitucionais em todo o mundo e sugere que o magistrado, individualmente, e o Judiciário, institucionalmente, exercem uma atividade importante de representação do interesse público. Esse papel exige, contudo, transformações institucionais capazes de ampliar a dimensão participava e deliberativa do processo de conformação interinstitucional das decisões políticas de modo a manter o sistema político sensível às demandas provenientes da esfera pública ampliada.

De acordo com essa abordagem, a jurisdição constitucional deve ser compreendida, ela mesma, como um espaço de exercício de representação política, ainda que de natureza distinta daquele que se estabelece tradicionalmente por meio da autorização eleitoral (Alexy 2005) e das instituições clássicas do governo representativo democrático, a saber, partidos e parlamentos. Destaca-se aí a capacidade das cortes constitucionais de acionarem a dimensão reflexiva da legitimidade democrática (Rosanvallon 2011), o que possibilita avançar na investigação dos modelos institucionais que a pluralidade discursiva é capaz de gerar.

Sob esse pano de fundo teórico, e com base nas noções de diálogo interinstitucional (Mendes 2013) e interface socioestatal (Isunza \& De La Raja 2006), enquanto categorias analíticas capazes de vincular os debates sobre a representação política e a deliberação nas cortes constitucionais, é que se procedeu à análise acerca dos impactos das audiências públicas, sobretudo em termos de inclusividade e ampliação da participação. A análise abarcou um período de oito anos durante os quais a corte fez um uso crescente do mecanismo das audiências públicas para ouvir a opinião de especialistas e representantes de instituições estatais e organizações civis a respeito de temas de grande relevância, complexidade e que envolviam intensa controvérsia pelos potenciais impactos nos campos jurídicos, político, social, econômico e cultural.

A análise permitiu concluir que, genericamente, os ministros do Supremo Tribunal Federal associam às audiências públicas grandes expectativas quanto à ampliação da legitimidade das decisões da corte, assim como quanto aos ganhos informacionais propiciados pelo mecanismo ao processo decisório, embora nem sempre vinculem uma variável à outra. Contudo, parece haver grande distância entre o discurso e a prática quando se considera a forma como as APs vêm sendo empregadas, muito aquém de suas potencialidades, particularmente em face ao grau elevado de discricionariedade do relator, com consequências negativas em termos de garantia quanto à inclusão equânime das partes.

Consideramos, com base nas evidências reunidas sobre o número e o perfil dos participantes das APs do STF, que este mecanismo pode funcionar como uma importante interface socioestatal, na medida em que conecta atores e instituições e propõe a efetiva conexão de um discurso público mais amplo levado a cabo em uma grande multiplicidade de esferas e arenas. Nesse sentido, seria interessante investigar, também, o potencial indutivo das APs no sentido de transformação da corte Constitucional em uma arena que promove o diálogo interinstitucional. Como próxima etapa de investigação, pretendemos investigar se as audiências podem fomentar processos deliberativos em outras arenas e contextos, para além do próprio Judiciário e, mesmo, da institucionalidade estatal (Mendes 2013). Os participantes, neste sentido, funcionariam como os elos que conectam processos deliberativos levados a cabo em uma multiplicidade de espaços e por uma variedade de meios (Almeida \& Cunha 2012; Mendonça 2013).

Embora tenha sido possível perceber um processo de institucionalização das APs, expressado pela própria alteração do Regimento Interno do Supremo Tribunal Federal (RISTF), e pela reiteração de um conjunto de práticas envolvidas 
na condução das audiências, a análise sugere que várias das diferenças identificadas entre os eventos devem ser explicadas mais pelo grau de adesão, pelas crenças, percepções e escolhas dos ministros do que por outros fatores como tema ou momento de realização da AP, o que expressa a enorme discricionariedade do relator e sua posição privilegiada na rede de atores envolvidos na construção do diálogo interinstitucional e socioestatal. Esta discricionariedade aponta, portanto, para a ausência de garantias institucionais para a inclusividade no processo.

$\mathrm{O}$ acentuado caráter instrutório de que ainda se revestem as APs, a rigidez na condução dos trabalhos por parte dos relatores, o baixo nível de interação dialógica entre as partes e o caráter sobejamente técnico-científico dos discursos são, sem dúvida, aspectos que contribuem para esse quadro. Vale lembrar, contudo, que houve avanço, quando se considera, comparativamente, as APs. Exemplarmente, conforme já referido, as audiências públicas referentes ao debate acerca da constitucionalidade das pesquisas com células-tronco embrionárias e da interrupção da gravidez em casos de anencefalia - cujas temáticas são similares - apresentaram diferentes padrões de inclusividade, sendo essa última muito mais plural quanto ao tipo de atores, linguagens e formatos discursivos admitidos.

A introdução do mecanismo das audiências públicas no âmbito do STF gera uma série de questões e problemas de pesquisa. Neste artigo, tentamos responder a algumas delas. Nas próximas etapas do projeto de investigação, cujos resultados parciais ora apresentamos, pretendemos avançar na compreensão de outros aspectos a partir do acesso mais completo às informações e dados. Permanecem sem respostas questões relativas ao porquê de alguns temas objeto de decisão na corte serem alvo de debate em audiência pública enquanto outros, igualmente complexos e controversos, não o foram; ou ainda, sobre qual o verdadeiro impacto das audiências públicas na decisão dos ministros - questão cuja resposta depende de uma análise pormenorizada dos votos; dentre outros. Uma análise mais detalhada e substantiva do conteúdo das audiências e o desenvolvimento de uma metodologia que nos permita identificar conexões entre as APs do STF e debates realizados em outras arenas são outros caminhos que permitirão, num futuro próximo, avançar nessa agenda de pesquisa.

Marjorie Corrêa Marona (maronamarjorie@gmail.com) é Doutora em Ciência Política pela Universidade Federal de Minas Gerais (UFMG) e Professora do Departamento de Ciência Política da mesma universidade. Vínculo Institucional: Departamento de Ciência Política, Universidade Federal de Minas Gerais, Belo Horizonte, MG, Brasil.

Marta Mendes da Rocha (mendes_rocha@yahoo.com.br) é Doutora em Ciência Política pela Universidade Federal de Minas Gerais (UFMG) e Professora do Departamento de Ciências Sociais da Universidade Federal de Juiz de Fora (UFJF). Vínculo Institucional: Programa de Pós-Graduação em Ciências Sociais, Universidade Federal de Juiz de Fora, Juiz de Fora, MG, Brasil.

\section{Referências}

Ackerman, B., 1993. We, the People. Cambridge, MA: Harvard University Press.

Ajouz, I. \& Almeida, C., 2013. Audiências Públicas na Suprema corte Brasileira: novas tendências para o diálogo social. Juris Poiesis, 16, pp.85-108.

Alexy, R., 2005. Teoria da Argumentação Jurídica: a teoria do discurso racional como teoria da fundamentação jurídica. $2^{\mathrm{a}}$ ed. São Paulo: Landy Editora.

Almeida, D., 2015. Representação além das eleições. Repensando as Fronteiras entre Estado e Sociedade. Jundiaí: Paco Editorial.

,2011.Repensando representação política e legitimidade democrática: entre a unidade e a pluralidade. Tese de Doutorado. Universidade Federal de Minas Gerais.

Almeida, D. \& Cunha, E.S.M., 2012. As dinâmicas da representação: a complexidade da interação institucional nas cidades brasileiras. In Congress of the Latin American Studies Association. San Francisco. 
Arantes, R., 2013. Cortes constitucionais. In L. Avritzer et al. eds. Dimensões Políticas da Justiça. Rio de Janeiro: Civilização Brasileira.

Ariede, E.B., 2011. Audiências Públicas no Supremo Tribunal Federal: um estudo comparativo de sua prática, antes e após o advento da Emenda Regimental n 29 de 2009. Monografia. São Paulo: Escola de Formação da Sociedade Brasileira de Direito Público.

Avritzer, L. 2009. Participatory Institutions in Democratic Brazil. Baltimore: The Johns Hopkins University Press. ,2016. Impasses da Democracia no Brasil. Rio de Janeiro: Civilização Brasileira.

Avritzer, L. \& Marona, M.C., 2014. Judicialização da Política no Brasil: ver além do constitucionalismo liberal para ver melhor. Revista Brasileira de Ciência Política, 15, pp.69-94. DOI: 10.1590/0103-335220141504

Baird, A., 2007. Answering the Call of the Court: How Justices and Litigants Set the Supreme Court Agenda. Charlottesville: University of Virginia Press.

Backes, A.L.; Azevedo, D.B. \& Araújo, J.C., eds. 2009. Audiências públicas na Assembleia Nacional Constituinte: a sociedade na tribuna. Brasília: Câmara dos Deputados.

Barbosa, C.M. \& Pamplona, D.A., 2011. A judicialização da política e as audiências públicas no Supremo Tribunal Federal. Revista Paradigma, 18, pp.69-78.

Barroso, L.R., 2015. A razão sem voto: o Supremo Tribunal Federal e o governo da maioria. Revista Brasileira de Políticas Públicas, 5(número especial), pp.24-50.

Bickel, A., 1986. The Least Dangerous Branch: The Supreme Court at the Bar of Politics. New Haven: Yale University Press.

Carvalho Neto, E., 2007. Revisão judicial e judicialização da política no direito ocidental: aspectos relevantes de sua gênese e desenvolvimento. Revista de Sociologia e Política, 28, pp.161-179. DOI: 10.1590/s0104-44782007000100011

, 2008. Dimensão política do acesso à justiça: aspectos da revisão judicial. In J.M.W. Gomes Neto, ed. Dimensões do acesso à Justiça. Salvador: Jus Podivm.

,2009. Judicialização da política no Brasil: controle de constitucionalidade e racionalidade política. Análise Social, 44, pp.315-335.

, 2010. Trajetória da revisão judicial no desenho constitucional brasileiro: tutela, autonomia e judicialização. Sociologias, 23, pp.176-207. DOI: 10.1590/s1517-45222010000100007

,2013. O poder dos juízes: Supremo Tribunal Federal e o desenho institucional do Conselho Nacional de Justiça. Revista de Sociologia e Política, 21(45), pp.13-27. DOI: 10.1590/s0104-44782013000100003

Checkoway, B., 1981. The Politics of Public Hearings. The Journal of Applied Behavioral Science, 17(4), pp.566-589. DOI: $10.1177 / 002188638101700411$

Couto, C.G. \& Arantes, R.B., 2006. Constituição, governo e democracia no Brasil. Revista Brasileira de Ciências Sociais, 21(61), pp.41-62. DOI: 10.1590/s0102-69092006000200003

Da Ros, L., 2013. Difícil hierarquia: a avaliação do Supremo Tribunal Federal pelos magistrados da base do Poder Judiciário no Brasil. Revista Direito GV, 9, pp.47-64. DOI: 10.1590/s1808-24322013000100003

, 2012. Juízes profissionais? Padrões de carreira dos integrantes das Supremas cortes de Brasil (1829-2008) e Estados Unidos (1789-2008). Revista de Sociologia e Política, 20(41), pp.149-169. DOI: 10.1590/s0104-44782012000100010

Dietz, T.; Stern, P.C. \& Rycroft, R.W., 1989. Definitions of Conflict and the Legitimation of Resources: The Case of Environmental Risk. Sociological Forum, 4(1), pp.47-69. DOI: 10.1007/bf01112616

Dworkin, R., 1995. Constitutionalism and Democracy. European Journal of Philosophy, 3(1), pp.2-11. DOI: 10.1017/cbo9780511490187.005

1999. Freedom's Law: The Moral Reading of the American Constitution. Oxford: Oxford University Press. , 2012. Justiça para ouriços. Coimbra: Almedina.

Elster, J. \& Slagstadt, R., 1988. Constitutionalism and Democracy. Cambridge, UK: Cambridge University Press.

Engelmann, F., 2015. Sentidos políticos da Reforma do Judiciário no Brasil. Revista Direito e Práxis, 6, pp.395-412. DOI: 10.12957/dep.2015.17304

Engelmann, F. \& Penna, L.R., 2014. Política na forma da lei: o espaço dos constitucionalistas no Brasil democrático. Lua Nova, 92, pp.177-206. DOI: 10.1590/s0102-64452014000200007

Engelmann, F. \& Cunha Filho, M.C., 2013. Ações judiciais, conteúdos políticos: uma proposta de análise para o caso brasileiro. Revista de Sociologia e Política, 21, pp.57-72. DOI: 10.1590/s0104-44782013000100006

Ferejohn, J. \& Pasquino, P., 2002. Constitutional Courts as Deliberative Institutions: Towards an Institutional Theory of Constitutional Justice. Law and Philosophy Library, 62, pp.21-36.

Fiorino, D., 1990. Citizen Participation and Environmental Risk: A Survey of Institutional Mechanisms. Science, Technology, and Human Values, 15(2), pp.226-243. DOI: 10.1177/016224399001500204

Fragale Filho, R., 2015. Audiências Públicas e seu impacto no processo decisório: a ADPF 54 como estudo de caso. Revista Direito \& Praxis, 6(12), pp.504-535. DOI: 10.12957/dep.2015.19230

Fraser, N., 2009. Scales of Justice: Reimagining Political Space in a Globalizing World. New York: Columbia University Press.

Friedman, B., 2009. The Will of the People: How Public Opinion Has Influenced the Supreme Court and Shaped the Meaning of the Constitution. London: Palgrave Macmillan.

Habermas, J., 1995. Três modelos normativos de democracia. Lua Nova, 36, pp.39-56. DOI: 10.1590/s0102-64451995000200003 
Isunza, E. \& De La Jara, F., 2006. Relaciones sociedad civil-estado en México: un ensayo de interpretación. Ciudad de México: Centro de Investigaciones y Estudios Superiores en Antropología Social.

Landemore, H., 2013. Democratic Reason: Politics, Collective Intelligence, and the Rule of the Many. Princeton: Princeton University Press.

Lavalle, A. \& Vera, E.I., 2011. A trama da crítica democrática: da participação à representação e à accountability. Lua Nova, 84, pp.353-364. DOI: 10.1590/s0102-64452011000300005

Leite, C.L.S., 2015. As audiências públicas no STF: mero instrumento de legitimação formal? In D. Sarmento, ed. Jurisdição Constitucional e Política. Rio de Janeiro: Editora Forense.

Lima, R.S.B., 2008. A Audiência Pública realizada na ADI 3510-0: A organização e o aproveitamento da primeira audiência pública da história do Supremo Tribunal Federal. Monografia. São Paulo: Escola de Formação da Sociedade Brasileira de Direito Público.

Maciel, D.A. \& Koerner, A., 2002. Sentidos da judicialização da política: duas análises. Lua Nova, 57, pp.113-133. DOI: 10.1590/s0102-64452002000200006

Marona, M.C. \& Rocha, M.M., 2014. As audiências públicas do Supremo Tribunal Federal: ampliando sua legitimidade democrática? Revista Teoria e Sociedade, 22-1, pp.53-86.

Mendes, C.H., 2011. Direito Fundamentais, Separação de Poderes e Deliberação. São Paulo: Editora Saraiva. 2013. Constitutional Courts and Deliberative Democracy. Oxford: Oxford University Press.

Mendonça, R.F., 2013. The Conditions and Dilemmas of Deliberative Systems. In 2013 Apsa Annual Meeting. Chicago.

Mendonça, R.F. \& Marona, M.C., 2015. O novo constitucionalismo e a teoria do reconhecimento: aproximações possíveis. In A.G. Lavalle; A. De Vita \& C. Araújo, eds. O Papel da Teoria Política Contemporânea: Justiça, Constituição, Democracia e Representação. São Paulo: Alameda.

Naves, A.L.G., 2012. Amicus curiae: uma investigação da participação social nas decisões do Supremo Tribunal Federal. Guimarães. Revista Brasileira de Estudos Constitucionais, 24, pp.943-972.

Nobre, M., 2008. Indeterminação e estabilidade: os 20 anos da Constituição Federal e as tarefas da pesquisa em direito. Novos Estudos, 82, pp.97-106. DOI: 10.1590/s0101-33002008000300005

Nobre, M. \& Rodriguez, J.R., 2011. Judicialização da política: déficits explicativos e bloqueios normativistas. Novos Estudos, 91, pp.5-20. DOI: 10.1590/s0101-33002011000300001

Oliveira, V.E., 2005. Judiciário e privatizações no Brasil: existe uma judicialização da política? Dados, 48, 3, pp.559-87.

Parkinson, J. \& Mansbridge, J., 2012. Deliberative Systems: Deliberative Democracy at the Large Scale. Cambridge, UK: Cambridge University Press.

Pessoa, L.B., 2012. O STF como ator de mudanças sociais relevantes: uma análise da ADPF 54. Monografia. São Paulo: Escola de Formação da Sociedade Brasileira de Direito Público.

Pires, R. \& Vaz, A., 2012. Participação social como método de governo? Um mapeamento das "interfaces socioestatais" nos programas federais. Brasília: Instituto de Pesquisa Econômica Aplicada.

Rawls, J., 1995. Liberalismo político. Ciudad de México: UNAM Editora. 2002. Uma teoria da justiça. São Paulo: Editora Martins Fontes.

Rodriguez, J.R., 2010. The Persistence of Formalism: Towards a Situated Critique beyond the Classic Separation of Powers. The Law and Development Review, 3(2), pp.41-77. DOI: 10.2202/1943-3867.1052

Rosanvallon, P., 2011. Democratic Legitimacy: Impartiality, Reflexivity, Proximity. Princeton: Princeton University Press.

Sachs, A., 2009. The Strange Alchemy of Life and Law. Oxford: Oxford University Press.

Sarmento, D., 2015. Jurisdição Constitucional e Política. Rio de Janeiro: Forense.

Souza, A. \& Jacobi, P.R., 2011. Licenciamento ambiental e ampliação da cidadania: o caso da hidrelétrica de Tijuco Alto. Organizações e Sociedade, 18(57), pp.245-263. DOI: 10.1590/s1984-92302011000200003

Sousa Santos, B., 2010. Refundación del Estado en América Latina: perspectivas desde una epistemología del Sur. Lima: Instituto Internacional de Derecho y Sociedad.

Tate, C.N. \& Vallinder, T., 1995. The Global Expansion of Judicial Power. New York: New York University Press.

Taylor, M.M. \& Da Ros, L., 2008. Os partidos dentro e fora do poder: a judicialização como resultado contingente da estratégia política. Dados, 51(4), pp.825-864. DOI: 10.1590/s0011-52582008000400002

Tomio, F.R.L. \& Robl Filho, I.N., 2015. Controle abstrato e concentrado de constitucionalidade comparado (Brasil, Portugal e Angola) e seus efeitos nas instituições sociais e jurídicas. História, 15, pp.181-197. DOI: 10.5335/hdtv.15n.1.5284

Tomio, F.R.L. \& Carvalho Neto, E., 2013. Dossiê política, direito e Judiciário: uma introdução. Revista de Sociologia e Política, 21(45), pp.7-11. DOI: 10.1590/s0104-44782013000100002

Topal, C., 2009. The Construction of General Public Interest: Risk, Legitimacy, and Power in a Public Hearing. Organization Studies, 30, 2-3, pp.277-300.DOI: 10.1177/0170840608101481

Waldron, J., 1994. Freeman's Defense of Judicial Review. Law and Philosophy, 13(1), pp.27-41. DOI: 10.2307/3504975 1999. Law and Disagreement. Gloucestershire: Clarendon Press.

Woolman, S. \& Bishop, M., 2008. Constitutional Conversations. Pretoria: Pretoria University Law Press.

Vianna, L.W.; Carvalho, M.A.R; Melo, M.P.C. \& Burgos, M.B., 1999. A judicialização da política e das relações sociais no Brasil. Rio de Janeiro: Reva

Vieira, O.V., 2008. Supremocracia. Revista Direito GV, 4(2), pp.441-463. DOI: 10.1590/s1808-24322008000200005

Vieira, O.V.; Dimoulis, D.; Lunardi, S.; Nassar, P.A. \& Glezer, R.E., 2013. Resiliência Constitucional. São Paulo: Direito G. 
Vestena, C.A., 2012. Audiências públicas: diagnóstico empírico sobre os limites da participação social. Revista Brasileira de Estudos Constitucionais, 24, pp.973-1020.

\section{Outras fontes}

STF. Supremo Tribunal Federal, 2008. Argüição de descumprimento de Preceito Fundamental 54-8. Disponível em: http://www.stf.jus.br/arquivo/cms/processoAudienciaPublicaAdpf54/anexo/ADPF54_notas_dia_4908.pdf. Acesso em: 5 jun. 2107.

,2010. Audiência Pública sobre Políticas de Ação Afirmativa de Reserva de Vagas no Ensino Superior. Disponível em: http://www.seppir.gov.br/portal-antigo/.arquivos/programacaostf.pdf/@@ download/file/programacaostf.pdf._Acesso em: 5 jun. 2017.

, s.d. Audiências Públicas. Disponível em: http://www.stf.jus.br/portal/audienciaPublica/audienciaPublica.asp?tipo =realizada. Acesso em: 5 jun. 2017. 


\section{Democratizing Constitutional Jurisdiction? Brazilian Supreme Court's Public Hearings Case}

\section{Abstract}

This article is part of a set of analyzes about judicialization of politics in Brazil, considering the performance of the Supreme Court (STF) in the exercise of judicial review. The object of analysis are the public hearings held by the Supreme Court from 2007 to 2014 . The aim is to verify to what extent the public hearings have been becoming a mechanism able to extend deliberative character of the Court and foster dialogue and interface between state actors societal ones, and, thus, widening the informational basis and the legitimacy of its decisions. All public hearings, excluding those for which the data were not available were analyzed. The study involved analysis in comparative perspective (longitudinal and transversal) mobilizing documental analysis from an analytical framework built around the dimensions of interest. A detailed characterization of public hearings was held - rules, issues, actors, frames and dynamic interaction. In addition, we seek to identify the common elements to the events, their singularities, changes over time, advances and limits regarding the use that the Court has been carrying the instrument. The article breaks new ground by exploring the theoretical possibilities associated with the analysis of the relationship between constitutionalism and democracy, starting from the dichotomous tradition that was established from the beginning of constitutional democracies even more recent dialogical perspectives. Considering the peculiarities surrounding the Supreme Court's role in recent years, it emphasizes the urgency of this debate for Brazil and proposes to review the operation of an institutional mechanism of relatively recent introduction. As far as are known by the authors there is no work that has been proposed to such a detailed analysis of Brazilian Supreme Court's public hearings.

KEYWORDS: public hearings; Brazilian Supreme Court; Legitimacy; Participation, Interinstitutional dialogue.

This is an Open Access article distributed under the terms of the Creative Commons Attribution Non-Commercial License which permits unrestricted non-commercial use, distribution, and reproduction in any medium provided the original work is properly cited. 